\title{
Choline is required in the diet of lactating dams to maintain maternal immune function
}

\author{
Neele S. Dellschaft ${ }^{1,2}$, Megan R. Ruth ${ }^{1}$, Susan Goruk ${ }^{1}$, Erin D. Lewis ${ }^{1}$, Caroline Richard ${ }^{1}$, \\ René L. Jacobs ${ }^{1}$, Jonathan M. Curtis ${ }^{1}$ and Catherine J. Field ${ }^{1 *}$ \\ ${ }^{1}$ Department of Agricultural, Food and Nutritional Science, University of Alberta, 4-126A Li Ka Shing Centre for Health \\ Research Innovation, Edmonton, AB, Canada T6G $2 E 1$ \\ ${ }^{2}$ Early Life Research Unit, Academic Division of Child Health, Obstetrics and Gynaecology, School of Medicine, \\ Queen's Medical Centre, The University of Nottingham, Nottingham NG7 2UH, UK
}

(Submitted 11 November 2014 - Final revision received 15 March 2015 - Accepted 20 March 2015 - First published online 23 April 2015)

\section{Abstract}

Choline demands during lactation are high; however, detailed knowledge is lacking regarding the optimal dietary intake during this critical period. The present study was designed to determine the effects of varying intakes of choline on maternal immune function during lactation. Primiparous Sprague-Dawley rats $(n$ 42) were randomised $24-48 \mathrm{~h}$ before birth and fed the following diets for $21 \mathrm{~d}$ : choline-devoid ( $0 \mathrm{~g}$ choline/kg diet; $\mathrm{D}, n$ 10); $1.0 \mathrm{~g}$ choline/kg diet (C1, $n$ 11); $2.5 \mathrm{~g}$ choline/kg diet (C2.5, $n$ 10); $6 \cdot 2 \mathrm{~g}$ choline/kg diet (C6, $n$ 11). Splenocytes were isolated and stimulated ex vivo with concanavalin A, lipopolysaccharide (LPS) or CD3/CD28. D and C6 dams had lower final body weight, spleen weight and average pup weight than $\mathrm{C} 1 \mathrm{dams}(P<0.05)$. There was a linear relationship between free choline concentration in pup stomach contents with maternal dietary choline content $\left(P<0 \cdot 001, r^{2} 0 \cdot 415\right)$. Compared with C1 and C2.5, D spleens had a lower proportion of mature $\mathrm{T}$ cells and activated suppressor cells, and this resulted in reduced cytokine production after stimulation $(P<0.05)$. Feeding $6.2 \mathrm{~g}$ choline $/ \mathrm{kg}$ diet resulted in a higher cytokine production after stimulation with $\mathrm{CD} 3 / \mathrm{CD} 28(P<0 \cdot 05)$. Except for a higher IL- 6 production after LPS stimulation with cells from the $\mathrm{C} 2.5$ dams $(P<0.05)$, there were no differences between the C1 and C2.5 dams. For the first time, we show that feeding lactating mothers a diet free of choline has substantial effects on their immune function and on offspring growth. Additionally, excess dietary choline had adverse effects on maternal and offspring body weight but only minimal effects on maternal immune function.

Key words: Choline: Immunology: Spleen: Lactation period: Growth

Choline is an essential nutrient that is a precursor for the cell membrane components phosphatidylcholine (PC) and sphingomyelin, required for synthesis of the neurotransmitter acetylcholine, and is a source of methyl groups for synthetic reactions ${ }^{(1,2)}$. The adverse effects of choline deficiency on liver lipid accumulation and muscle dystrophy are well established across species ${ }^{(3,4)}$. Previous studies have demonstrated that the demand for choline increases significantly during lactation, and that it is required for optimal growth and development of the infant ${ }^{(5,6)}$. However, the diet of women during lactation may not be meeting this increase. Our recent cohort study has found that the majority of lactating women were consuming well below the present recommended 'adequate intake' level ${ }^{(7)}$.

Dietary nutrients can modify and optimise immune function, and this may be particularly important during lactation since the high nutrient requirements of breast milk might limit the availability of nutrients to the mother. It has been demonstrated that choline is essential during pregnancy for the offspring, and an early study has reported that dams fed diets devoid or marginally deficient in dietary lipotropes (including choline and folate) had pups more susceptible to infection in postnatal life, and this could not be corrected by postnatal supplementation ${ }^{(8)}$. Furthermore, choline is a structural component of acetyl-choline, which, in addition to its role as a neurotransmitter, has been demonstrated to be involved in mediating the anti-inflammatory response of the vagus nerve ${ }^{(9)}$. Optimising the immune system in the dam is not only important for the composition of breast milk ${ }^{(10)}$ but also for the health of the mother ${ }^{(11)}$.

PC and sphingomyelin have critical structural and functional roles in cell membranes, and alterations in these molecules

Abbreviations: $\mathrm{C} 1,1.0 \mathrm{~g}$ choline/ $\mathrm{kg}$ diet; C2.5, $2.5 \mathrm{~g}$ choline/kg diet; C6, $6.2 \mathrm{~g}$ choline/kg diet.; ConA, concanavalin A; D, choline-deficient diet; GPC, glycerophosphocholine; LPS, lipopolysaccharide; Pcho, phosphocholine; PC, phosphatidylcholine.

*Corresponding author: Dr C. J. Field, fax +1 780492 2011, email catherine.field@ualberta.ca 
due to choline deficiency would be predicted to impair immune function. However, due to the high demands of the placenta, fetus and infant (breast milk) and the reported depletion of maternal choline status during pregnancy and lactation, one would predict that a less than adequate intake of choline would also have adverse effects on immune cell function. Only one previous feeding study has examined the effects of choline deficiency on immune function in adult female rats. Courrèges et $a l^{(12)}$ reported that, relative to a diet containing $2.6 \mathrm{~g}$ choline $/ \mathrm{kg}$ (fed as $3.5 \mathrm{~g}$ choline chloride $/ \mathrm{kg}$ ), 60-d-old rats consuming a diet devoid of choline for 3 weeks had lower delayed-type hypersensitivity responses and ex vivo their splenocytes had a significantly reduced response to concanavalin A (ConA) stimulation. As there was no effect of the devoid diet on the proliferative response to lipopolysaccharide (LPS), the authors concluded that primarily T-cell function was affected. The optimal level of dietary choline required to support maternal immune function has not been established. Although an exogenous source of choline is required in rats during lactation ${ }^{(6)}$, the implications of differing levels of intake of choline during lactation on maternal immunity have not been studied. Therefore, the connection between choline intake during lactation and maternal and infant immunity merits further research.

The purpose of the present study was to compare the parameters of maternal immune function and pup growth during suckling when mothers are fed a diet containing the recommended minimal concentration (AIN-93G/ $\mathrm{M}^{(13)}$ ) found in most commercial rodent chows ( $1 \mathrm{~g}$ choline $/ \mathrm{kg}$ diet) to (1) a choline-devoid diet, (2) a diet containing the amount of choline that can be found in many high-fat diets $(2.5 \mathrm{~g}$ choline $/ \mathrm{kg}$ diet) and (3) a diet containing a higher amount of choline (6g choline/kg diet) representing 2.5-6 times the concentration usually found in commercial rodent diets. We hypothesise that not providing choline in the diet during lactation will adversely affect maternal immune function and that intake above the current minimum recommendation of $1 \mathrm{~g}$ choline/ $\mathrm{kg}$ in rodent diets ${ }^{(13)}$ will improve immune cell function.

\section{Experimental methods}

\section{Animals and diets}

Primiparous Sprague-Dawley rats ( $n$ 42) were obtained from Charles River Laboratories on day 14 of gestation. Dams were fed standard rat chow (Lab diet 5001; PMI Nutrition International, containing $1 \mathrm{~g}$ choline/kg; Harland Teklad) throughout gestation, then randomised to one of four experimental diets (Table 1) $24-48 \mathrm{~h}$ before parturition. This timing was selected to ensure that the dam had the experimental diet at the initiation of suckling. The initial body weight of the dams at the time point of birth did not differ significantly between the experimental groups (271 (SEM 5) g, $n$ 40). The content of choline in the salt was verified by analysis ${ }^{(14)}$, before adding it to the diets. Diets were fed ad libitum throughout lactation to the end of the study at $21 \mathrm{~d}$ postnatal. Animals were provided free access to food throughout each $24 \mathrm{~h}$ period, and the feed cups were dumped and refilled every 2-3d. The four experimental diets were isoenergetic, isonitrogenous and differed only in the content of choline provided in the form of choline bitartrate (Table 1 ): devoid choline ( $0 \mathrm{~g}$ choline $/ \mathrm{kg}$ diet; $\mathrm{D}, n 8)$ or sufficient choline, containing $1.0 \mathrm{~g}$ choline $/ \mathrm{kg}$ diet (C1, $n$ 11), $2.5 \mathrm{~g} / \mathrm{kg}(\mathrm{C} 2 \cdot 5, n 10)$, or $6 \cdot 2 \mathrm{~g} / \mathrm{kg}$ (C6, $n$ 11). At birth, litters were standardised to ten pups (five males and five females when possible) per dam. Dietary intake and body weight were recorded regularly throughout lactation. Two of the original ten dams in the D group had to be killed before the end of the experiment due to significant weight loss. The protocol was reviewed and approved by the Committee of Animal Policy and Welfare of the Faculty of Agricultural, Life and Environmental Sciences at the University of Alberta, Edmonton, Alberta, Canada.

\section{Tissue collection}

After 21 days of parturition, dams and two pups per dam were weighed and killed by $\mathrm{CO}_{2}$ asphyxiation and subsequent cervical dislocation in the morning hours. The dams were killed in the AM at the end of the dark cycle, under the assumption that the dams were in the postprandial state. Spleens and livers were collected, weighed and immune cells isolated from the spleen. Pups' stomach contents were collected aseptically, weighed, snap-frozen in liquid $\mathrm{N}_{2}$ and stored at $-80^{\circ} \mathrm{C}$ until analysis.

\section{Liver total fat content}

Total fat was isolated from dam and offspring livers using a modification of the Folch method ${ }^{(15)}$. After defrosting, $300 \mathrm{mg}$ of liver tissue were homogenised in $1 \mathrm{ml}$ of $0.025 \%$

Table 1. Composition of experimental diets

\begin{tabular}{lcccc}
\hline Component (g/kg diet) & D & C1 & C2.5 & C6 \\
\hline Casein (high protein) & 270 & 270 & 270 & 270 \\
Starch & 244 & 241 & 238 & 232 \\
Dextrose & 126 & 126 & 126 & 126 \\
Vitamin mix (AIN 93) & 19 & 19 & 19 & 19 \\
Bernhardt-Tomarelli mineral mix & 50 & 50 & 50 & 50 \\
Calcium phosphate dibasic & $3 \cdot 4$ & $3 \cdot 4$ & $3 \cdot 4$ & $3 \cdot 4$ \\
Inositol & $6 \cdot 3$ & $6 \cdot 3$ & $6 \cdot 3$ & $6 \cdot 3$ \\
Cellulose & 80 & 80 & 80 & 80 \\
Marinol & $2 \cdot 4$ & $2 \cdot 4$ & $2 \cdot 4$ & $2 \cdot 4$ \\
Flax oil & 7 & 7 & 7 & 7 \\
Olive oil & 48 & 48 & 48 & 48 \\
Sunflower oil & 67 & 67 & 67 & 67 \\
Canola stearin & $75 \cdot 6$ & $75 \cdot 6$ & $75 \cdot 6$ & $75 \cdot 6$ \\
Cys & $1 \cdot 8$ & $1 \cdot 8$ & $1 \cdot 8$ & $1 \cdot 8$ \\
Choline bitartrate & 0 & $2 \cdot 5$ & $6 \cdot 0$ & 15 \\
\% Energy from protein & 25 & 25 & 25 & 25 \\
\% Energy from carbohydrate & 34 & 34 & 34 & 34 \\
\% Energy from fat & 41 & 41 & 41 & 41 \\
Choline g/kg (nmol/kg) $\ddagger$ & 0 & $1 \cdot 0$ & $2 \cdot 5$ & $6 \cdot 2$ \\
\hline
\end{tabular}

$\mathrm{D}$, choline-deficient diet; C1, $1.0 \mathrm{~g}$ choline $/ \mathrm{kg}$ diet; $\mathrm{C} 2.5,2.5 \mathrm{~g}$ choline/ $\mathrm{kg}$ diet; C6, $6.2 \mathrm{~g}$ choline $/ \mathrm{kg}$ diet.

* All ingredients were purchased from Harland Teklad with the exception of the dietary oils that were purchased from Safeway, Marinol was donated by Lipid Nutrition, and the stearin was purchased from CanAmera.

$\ddagger$ Choline was added to the diets in the form of choline bitartrate (Harland Teklad) reach the desired choline concentration for the four diets. 
calcium chloride solution for $30 \mathrm{~s}$ at $6.5 \mathrm{~m} / \mathrm{s}$ using a FastPrep24 homogeniser (MP Biomedicals). In glass tubes, $12 \mathrm{ml}$ of 2:1 chloroform-methanol and $1 \mathrm{ml}$ of $0.025 \%$ calcium chloride solution were added to the liver homogenate. These tubes were vortexed thoroughly and left overnight at $4^{\circ} \mathrm{C}$. This treatment results in two layers and the lower, chloroform phase was transferred into a new, pre-weighed, glass tube and the remaining phase washed once more with 2:1 chloroformmethanol. After $1 \mathrm{~h}$, the chloroform phase of the second wash was added to the first aliquot. The chloroform was evaporated under $\mathrm{N}_{2}$ until only the fat remained in the tube that was reweighed, with the difference between the two weights being the weight of the fat extracted. Total liver fat was expressed as mass of fat adjusted for original sample weight $(\mathrm{mg} / \mathrm{g})$.

\section{Choline metabolite analyses of pup stomach content}

Rat pup stomach contents were used to determine the effect of maternal diet on the content of choline in the dam's milk. Frozen stomach contents were ground on liquid $\mathrm{N}_{2}$, and lipids were then extracted by a modified method following Bligh \& Dyer ${ }^{(16)}$ as described in detail previously ${ }^{(14)}$. All of the significant classes of choline-containing compounds in the extracts were quantified by hydrophilic interaction chromatography (HILIC) liquid chromatography-tandem MS (LC-MS/MS) using an Agilent 1200 series HPLC system coupled to a 3200 QTRAP mass spectrometer (AB SCIEX) as previously described in detail ${ }^{(14)}$. Data were acquired and analysed with the use of Analyst 1.4.2 software. The total choline content and proportion of choline per molecule were calculated using the molecular weights of choline and the choline-containing molecules.

\section{Immune cell isolation}

Immune cells were isolated from spleens as described previously ${ }^{(17)}$. Briefly, single-cell suspensions were obtained by disrupting tissue through a nylon mesh screen in sterile Krebs-Ringer HEPES buffer with bovine serum albumin ( $5 \mathrm{~g} / 1$; Sigma-Aldrich Canada Limited). Erythrocytes were removed from the mixture by treatment with ammonium chloride lysis buffer ( $155 \mathrm{~mm}-\mathrm{NH}_{4} \mathrm{Cl}, 0 \cdot 1 \mathrm{~mm}$-EDTA, $10 \mathrm{~mm}-\mathrm{KHCO}_{3}$; Fisher Scientific). Cells were washed and re-suspended in complete culture medium (Roswell Park Memorial Institute (RPMI) 1640 media (Life Technologies)) supplemented with $5 \%(\mathrm{v} / \mathrm{v})$ heat-inactivated fetal calf serum, 25 mM-HEPES, $2.5 \mathrm{~mm}$-2-mercaptoethanol and $1 \%$ antibiotic/antimycotic ( $\mathrm{pH} 7 \cdot 4$; Fisher Scientific, as earlier). Cells were counted on a haemocytometer using trypan blue dye exclusion (SigmaAldrich, as above) and diluted to $1.25 \times 10^{6}$ cells $/ \mathrm{ml}$.

\section{Immune cell phenotype analysis}

Immune cell subsets in freshly isolated splenocytes were identified by direct immunofluorescence assay as described previously ${ }^{(17,18)}$. In brief, 200000 immune cells were incubated for $30 \mathrm{~min}$ at $4^{\circ} \mathrm{C}$ with pre-labelled monoclonal antibodies applied in combination to quantify various immune cell phenotypes. Four-colour flow cytometry allowed determination of the following surface molecule combinations: CD28/ CD3/CD8/CD4, CD4/CD8/CD152, CD25/CD8/CD4, CD3/CD71/ CD8/CD4, CD3/CD45RA/CD27, CD68/CD284/CD11b/c, CD3/ CD161, CD8/OX62/OX6, IgG/IgM, CD3/CD25/FOXP3/CD4 and $\mathrm{OX} 12 / \mathrm{CD} 27$. All mAb with the exception of $\operatorname{IgG}$, IgM and OX6 (BD Biosciences) were purchased from Cedarlane Laboratories. After incubation, cells were washed and fixed in paraformaldehyde (10 g/l; ThermoFisher) in PBS. To identify the intracellular protein forkhead box P3 (FOXP3), isolated cells were permeabilised before addition of the antibody, according to the manufacturer's directions (Cedarlane Laboratories).

All samples were acquired within $72 \mathrm{~h}$ by flow cytometry (FACSCalibur; Becton Dickinson) and analysed according to the relative fluorescence intensity using Kaluza Software (Beckman Coulter).

\section{Ex vivo cytokine secretion by mitogen-stimulated splenocytes}

Cytokine production by mitogen-stimulated splenocytes was measured as described previously ${ }^{(19)}$. In brief, immune cells $\left(1.25 \times 10^{6}\right.$ cells $\left./ \mathrm{ml}\right)$ were cultured in $1 \mathrm{ml}$ (RMPI-1640 medium as above) for $48 \mathrm{~h}$ at $37^{\circ} \mathrm{C}$ and $5 \% \mathrm{CO}_{2}$ without mitogen (unstimulated cells) or with ConA $(2.5 \mu \mathrm{g} / \mathrm{ml}$; MP Biomedicals), LPS (100 $\mu \mathrm{g} / \mathrm{ml}$; Sigma-Aldrich, as above) or both $\operatorname{CD} 3(1 \mu \mathrm{g} / \mathrm{ml})$ and $\operatorname{CD} 28(5 \mu \mathrm{g} / \mathrm{ml}$; both from e-Bioscience, Inc.). Cells were then centrifuged for $10 \mathrm{~min}$ at $1000 \mathrm{rpm}$ and the supernatants kept at $-80^{\circ} \mathrm{C}$ until analyses. Commercial ELISA kits were used to measure the concentrations of IL-1 $\beta$, IL-2, IL-6, IL-10, TNF- $\alpha$ and interferon- $\gamma$ (IFN- $\gamma$ ) according to the manufacturer's instructions and as described previously ${ }^{(19)}$. All detection limits were 15.63$4000 \mathrm{pg} / \mathrm{ml}$ except IFN- $\boldsymbol{\gamma}, 9 \cdot 76-2500 \mathrm{pg} / \mathrm{ml}$ (R\&D systems). Concentrations were determined on a microplate reader (SpectraMax 190; Molecular Devices), and all measurements were conducted in duplicate with $\mathrm{CV}<10 \%$.

\section{Statistical analysis}

Statistical analyses were conducted using SAS statistical software (version 9.3; SAS Institute, Inc.). Data were analysed for normal distribution in each dietary group with the use of a Kolmogorov-Smirnov test. Parametric data were subsequently analysed for differences by ANOVA and Tukey post hoc testing was used. Regression analysis was used to test the relationship between dietary choline intake and the concentration of free and total choline in the stomach content of the offspring. Non-parametric data were log-transformed before analysis by ANOVA as above. In some instances, logtransformation did not lead to normal distribution of the data, and groups were compared similarly using MannWhitney $U$-tests. For all statistical tests, significance was accepted with a CI of $95 \%(P<0 \cdot 05)$. All results are presented as means with their standard errors and the actual number of values available for each measure is indicated with the results. 


\section{Results}

\section{Anthropometric characteristics}

Dams fed the choline-deficient diet, D, had lower final body weights, spleen weights and average pup weight per dam compared with the $\mathrm{C} 1$ diet $(P<0 \cdot 05$; Table 2). Dams fed the diet with a high dose of choline, C6, had lower final body weight compared with the $\mathrm{C} 1$ and $\mathrm{C} 2.5$ dams, and had lower spleen weight and lower average pup weight at $21 \mathrm{~d}$ postnatal than $\mathrm{C} 1$ dams $(P<0.05$; Table 2$)$. Food intake in D dams was $29 \%$ lower compared with C1 $(P<0.05$, Table 2$)$. Food intake in C6 dams was $24 \%$ lower than C1 $(P<0 \cdot 05$, Table 2). Neither splenocyte numbers nor liver fat weight differed between any of the groups.

\section{Choline metabolites in pup stomach contents}

The total choline content in the pups' stomachs was significantly lower in D compared with C1, C2.5 and C6 pups (Fig. 1), and there was a linear relationship between dietary choline content and total choline concentration in the offspring's stomach $\left(R^{2} 0 \cdot 28, P<0 \cdot 001\right)$. The difference in choline content between groups in the stomach content was primarily due to differences in the free choline content (Table 3), which also had a linear relationship with maternal dietary choline content $\left(R^{2} 0.42, P<0 \cdot 001\right)$. Glycerophosphocholine (GPC) concentration was lower and lysophosphocholine concentration was higher in D stomach contents compared with pups of choline-sufficient mothers. These differences in total concentrations resulted in differences in the relative contribution of choline-containing molecules to the total choline content (Fig. 1). In D pups, the relative contributions of sphingomyelin, lysophosphocholine and phosphocholine (Pcho) to total choline content were significantly higher than in the other groups, due to the low content of free choline (Fig. 1). In C6 pups, due to the high concentration of free choline, the relative contribution of Pcho and GPC was lower than in $\mathrm{C} 1$ pups (Fig. 1). There were no significant differences in the absolute or relative concentrations of choline metabolites, between $\mathrm{C} 1$ and $\mathrm{C} 2.5$ pups' stomach contents (Table 3 and Fig. 1).

\section{Immune cell phenotypes}

While splenocyte numbers were similar between groups, spleen-derived immune cell distributions differed between groups. Compared with C1, D dam spleens had a lower proportion of $\mathrm{CD} 4+\mathrm{T}$ cells $(\% \mathrm{CD} 3+\mathrm{CD} 4+$, T helper cells; $P<0.05$; Table 4). D also had a lower proportion of CD4+ $(\mathrm{CD} 3+\mathrm{CD} 4+)$ and $\mathrm{CD} 8+$ cells $(\mathrm{CD} 3+\mathrm{CD} 8+)$ expressing the co-stimulatory molecule $\mathrm{CD} 28 \quad(P<0 \cdot 05$; Table 4$)$. Although we found no difference in the proportion of total CD8+ cells, the proportion of CD8+ cells that expressed either the IL-2 receptor (CD25), the cytotoxic T-lymphocyteassociated protein 4 (CTLA-4, CD152), or the transferrin receptor $(\mathrm{CD} 71)$ were higher $(P<0.05)$ in spleens from $\mathrm{D}$ compared with $\mathrm{C} 1$ dams (Table 4). There was a lower proportion of $\mathrm{CD} 3+\mathrm{CD} 4+$ cells; however, the percentage of the $\mathrm{CD} 4+$ population that was positive for $\mathrm{CD} 152$ was higher in D than in C1 and C2.5 dams (Table 4). There was no difference in the relative proportion of $\mathrm{T}$ regulator cells $(\mathrm{CD} 4+\mathrm{CD} 25+\mathrm{FOXP} 3+)$. D spleens had a higher $(P<0 \cdot 05)$ proportion of cells expressing MHC class II (OX6+); however, the proportion of macrophages (CD68+ and $\mathrm{CD} 11 \mathrm{~b} / \mathrm{c}+$ ) did not differ between groups (Table 4). Total B (Ig+ cells, $\mathrm{OX} 12+)$ and IgG+ cells comprised a higher percentage of splenocytes in D mothers (Table 4). However, the proportion of B cells (OX12+) that expressed the TNF receptor (CD27) was lower in the D group $(P<0 \cdot 05)$. Although only comprising a small proportion of total splenocytes, dendritic cells (OX62+OX6+) were 2-fold higher $(P<0.05)$ in the spleen of dams fed D (Table 4). Compared with the groups fed a diet with a normal choline content, feeding a diet with a higher choline content, $\mathrm{C} 6$, made no difference in the types of immune cells in the spleen, except for a lower proportion of $\mathrm{CD} 3+\mathrm{CD} 4+$ cells $(P<0 \cdot 05$; Table 4$)$.

\section{Cytokine production}

There was a significantly lower $(P<0.05)$ production of cytokines produced after stimulation with LPS (IL-10 and IFN- $\gamma$ ), ConA (IL-2, IL-6, TNF- $\alpha$ and IFN- $\gamma$ ) and CD3/CD28 (IL-2, IL-6, IL-10 and IFN- $\gamma$ ) in D compared with cells from animals that

Table 2. Anthropometric data of lactating dams fed choline-deficient (D) or choline-sufficient diets (C1, C2.5 or C6) at the end of the study, $21 \mathrm{~d}$ postnatal ${ }^{\star}$

(Mean values with their standard errors)

\begin{tabular}{|c|c|c|c|c|c|c|c|c|}
\hline & \multicolumn{2}{|c|}{$\mathrm{D}(n 8)$} & \multicolumn{2}{|c|}{$\mathrm{C} 1(n 11)$} & \multicolumn{2}{|c|}{$\mathrm{C} 2 \cdot 5(n 10)$} & \multicolumn{2}{|c|}{ C6 (n 11) } \\
\hline & Mean & SEM & Mean & SEM & Mean & SEM & Mean & SEM \\
\hline Body weight (g, $21 \mathrm{~d}$ postnatal) & $204^{\mathrm{b}}$ & 4 & $246^{a}$ & 5 & $235^{\mathrm{a}}$ & 6 & $209^{b}$ & 7 \\
\hline Spleen weight (g) & $0.39^{\mathrm{b}}$ & 0.03 & $0.53^{\mathrm{a}}$ & 0.03 & $0.48^{\mathrm{a}, \mathrm{b}}$ & 0.04 & $0.40^{\mathrm{b}}$ & 0.02 \\
\hline Spleen weight (mg/g body weight) & 1.9 & 0.2 & $2 \cdot 2$ & 0.1 & $2 \cdot 0$ & 0.2 & 1.9 & 0.1 \\
\hline Splenocytes/g spleen $\left(\times 10^{6}\right)$ & 210 & 40 & 249 & 40 & 228 & 34 & 234 & 30 \\
\hline Gonadal fat weight (mg/g body weight) & $3 \cdot 5^{\mathrm{a}, \mathrm{b}}$ & 0.8 & $2 \cdot 4^{\mathrm{a}, \mathrm{b}}$ & 0.4 & $2 \cdot 1^{\mathrm{b}}$ & 0.3 & $4 \cdot 2^{\mathrm{a}}$ & 0.8 \\
\hline Liver fat weight (mg/g liver) & 27 & 9 & 22 & 3 & 20 & 4 & 23 & 7 \\
\hline Food intake $(\mathrm{g} / \mathrm{d})$ & $30^{\mathrm{b}}$ & 3 & $42^{\mathrm{a}}$ & 2 & $42^{\mathrm{a}}$ & 3 & $32^{b}$ & 3 \\
\hline Average pup weight (g, 21d) & $26^{\mathrm{c}}$ & 1 & $40^{\mathrm{a}}$ & 3 & $38^{\mathrm{a}}$ & 3 & $32^{\mathrm{b}}$ & 1 \\
\hline
\end{tabular}

${ }_{\mathrm{a}, \mathrm{b}, \mathrm{c}}$ Mean values within a row with unlike superscript letters were significantly different $(P<0.05)$.

* There was no significant difference between males and females, so the entire litter was pooled to represent the average pup weight. Discrepancies between total number of mothers per group and the number here depicted are due to technical difficulties. 
(A)

D diet $\left(6 \cdot 2 \pm 1 \cdot 0^{\mathrm{a}} \mathrm{mg} / 100 \mathrm{~g}\right)$

(B)
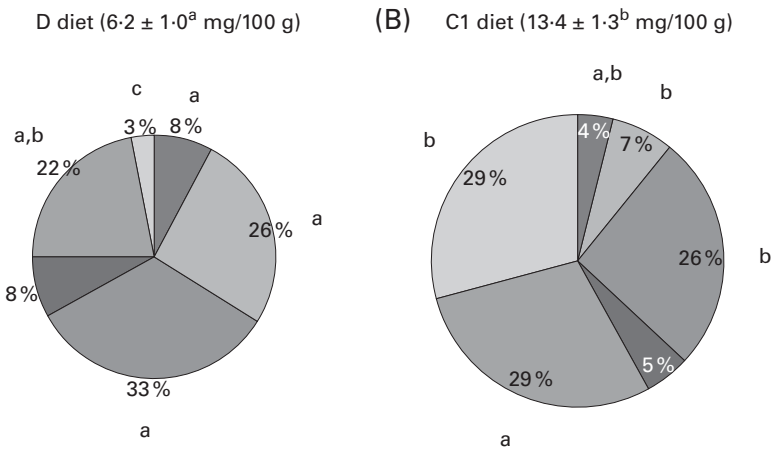

(C)

C2.5 diet $\left(14 \cdot 1 \pm 1 \cdot 3^{\mathrm{b}} \mathrm{mg} / 100 \mathrm{~g}\right)$

(D)

$\mathrm{C} 6 \operatorname{diet}\left(20 \cdot 7 \pm 4 \cdot 0^{\mathrm{b}} \mathrm{mg} / 100 \mathrm{~g}\right)$

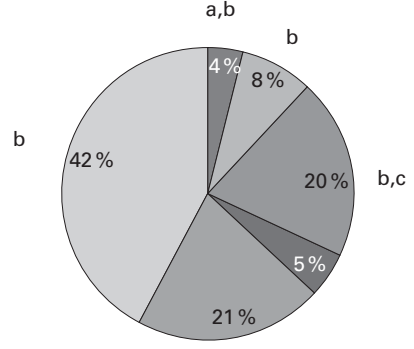

$\mathrm{a}, \mathrm{b}$

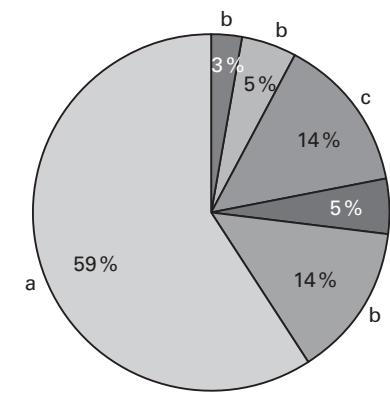

Fig. 1. Total choline content and relative contribution of the different forms of choline in the pups' stomach contents at $21 \mathrm{~d}$ postnatal from mothers who were fed one of four diets during lactation: (A) choline-devoid diet (D diet; $n$ 6); (B) $1 \mathrm{~g} / \mathrm{kg}$ choline diet (C1 diet; $n 11)$; (C) $2.5 \mathrm{~g} / \mathrm{kg}$ choline diet (C2.5 diet; $n$ 8); (D) $6.2 \mathrm{~g} / \mathrm{kg}$ choline diet (C6 diet; $n$ 10). Discrepancies between the total number of mothers per group and the numbers shown here are due to technical difficulties. Total choline content in the $D$ diet was significantly different from that in all the other diets $(P<0.05)$. Total choline content did not differ between the $\mathrm{C} 1, \mathrm{C} 2.5$ and $\mathrm{C} 6$ diets. Data are means with their standard errors for the total content. Values are means for the percentage composition of the total choline content within each chart. ${ }^{a, b, c}$ Differences in the relative content of choline originating from the different forms are indicated by letters next to the pie charts, indicating that between charts, wedges (clockwise from the top, sphyingomyelin $(\square)$, lipopolysaccharide ( $\square$ ), phosphocholine $(\square)$, phosphatidylcholine $(\square)$, glycerophosphocholine $(\square)$ and free choline $(\square))$ with unlike letters were significantly different $(P<0.05)$.

received choline (C1, C2.5 and C6; Table 5). Production of cytokines did not differ in ConA-stimulated splenocytes from C1, C2.5 and C6 dams. There was also no difference in the cytokine response to $\mathrm{CD} 3 / \mathrm{CD} 28$ between the $\mathrm{C} 1$ and $\mathrm{C} 2 \cdot 5$ group; however, splenocytes from C6 dams produced more IL-2, IL-6 and TNF- $\alpha(P<0 \cdot 05$; Table 5$)$. Splenocytes from C2.5 and C6 dams produced more IL- 6 after stimulation with LPS than those from C1 dams $(P<0 \cdot 05$; Table 5$)$.

\section{Discussion}

We have established that choline is an essential micronutrient during lactation, and that endogenous synthesis, contributing to the concentration of choline in mother's milk ${ }^{(20)}$, is not sufficient to ensure optimal growth in the offspring. In the present study, we found that the amount of choline salt in the maternal diet influences the content of choline that is provided to the offspring. As the total choline concentration in milk has been reported to be directly associated with the infant's circulating choline concentration ${ }^{(21)}$, the present results suggest that we can alter the choline status of the offspring by feeding choline to suckling dams even at levels beyond the current requirement for growth. In D offspring's stomach content, the sample we used to represent mother's milk contents, we showed a reduction in GPC by $50 \%$. GPC content in the mammary gland is either synthesised from Pcho ${ }^{(20)}$ or by phospholipase-mediated breakdown of $\mathrm{PC}^{(22)}$. As the content of Pcho and PC was not lower in D stomach contents, this suggests that substrate availability may not have been the limiting factor in the synthesis of GPC. Alternatively, the lower content of GPC could suggest that choline is being partitioned away from GPC synthesis in the dam to meet other biological needs. The higher concentration of lysophosphocholine in D stomach contents suggests that the action of phospholipase A.2, the enzyme enabling GPC synthesis, may have been inhibited in the mammary glands of the D dams. In contrast to our findings, a rat study feeding a choline-devoid diet during lactation has found a lower concentration of Pcho ${ }^{(20)}$. The relative composition of choline metabolites in the pups' stomach contents in the present study is consistent with that reported for human milk ${ }^{(23)}$, which may be due to the shared higher fat content. This difference from the previously published study may be due to the high-fat diet used in the present study, which provided considerably more fat as a percentage of energy than the $10 \%$ provided in the standard AIN-76a diet.

Table 3. Choline content from the choline-containing molecules $(\mathrm{mg} / 100 \mathrm{~g})$ of rat pup stomach contents from dams fed choline-deficient (D) or choline-sufficient diets (C1, C2.5 or C6)* (Mean values with their standard errors)

\begin{tabular}{|c|c|c|c|c|c|c|c|c|}
\hline & \multicolumn{2}{|c|}{$\mathrm{D}(n 6)$} & \multicolumn{2}{|c|}{$\mathrm{C} 1(n 11)$} & \multicolumn{2}{|c|}{$\mathrm{C} 2.5(n 8)$} & \multicolumn{2}{|c|}{ C6 (n 10) } \\
\hline & Mean & SEM & Mean & SEM & Mean & SEM & Mean & SEM \\
\hline Cho & $0.2^{c}$ & 0.1 & $3.9^{b}$ & 0.5 & $6 \cdot 2^{\mathrm{a}, \mathrm{b}}$ & $1 \cdot 3$ & $13 \cdot 1^{a}$ & $3 \cdot 2$ \\
\hline $\mathrm{PC}$ & 0.4 & 0.1 & 0.5 & 0.1 & 0.7 & 0.1 & 0.6 & 0.1 \\
\hline Lyso-PC & $1 \cdot 3^{a}$ & 0.1 & $0.9^{a, b}$ & 0.1 & $1 \cdot 0^{\mathrm{a}, \mathrm{b}}$ & 0.1 & $0.9^{b}$ & 0.1 \\
\hline Sphingomyelin & 0.5 & 0.1 & 0.5 & 0.1 & 0.6 & 0.1 & 0.5 & $0 \cdot 1$ \\
\hline GPC & $1 \cdot 6^{\mathrm{b}}$ & 0.5 & $4 \cdot 0^{\mathrm{a}}$ & 0.6 & $2 \cdot 8^{\mathrm{a}, \mathrm{b}}$ & 0.2 & $2 \cdot 9^{a, b}$ & 0.6 \\
\hline Phosphocholine & $2 \cdot 2$ & 0.6 & 3.5 & 0.6 & $2 \cdot 8$ & 0.6 & $2 \cdot 7$ & 0.7 \\
\hline
\end{tabular}

Cho, free choline; PC, phosphatidylcholine; Lyso-PC, lysophosphatidylcholine; GPC, glycerophosphocholine.

a,b,c Mean values within a row with unlike superscript letters were significantly different $(P<0.05)$.

${ }^{*}$ Concentrations calculated per $100 \mathrm{~g}$ total stomach contents. Discrepancies between total number of mothers per group and the number here depicted are due to technical difficulties. 
Table 4. Splenocyte phenotypes of lactating rat dams fed choline-deficient (D) or choline-sufficient diets (C1, C2.5 or C6)* (Mean values with their standard errors)

\begin{tabular}{|c|c|c|c|c|c|c|c|c|}
\hline & \multicolumn{2}{|c|}{$\mathrm{D}(n 6)$} & \multicolumn{2}{|c|}{ C1 (n 11) } & \multicolumn{2}{|c|}{$\mathrm{C} 2.5(n 10)$} & \multicolumn{2}{|c|}{ C6 (n 11) } \\
\hline & Mean & SEM & Mean & SEM & Mean & SEM & Mean & SEM \\
\hline & \multicolumn{8}{|c|}{$\%$ Total cells } \\
\hline Total CD3+ & $42^{b}$ & 4 & $49^{a}$ & 2 & $49^{\mathrm{a}}$ & 1 & $49^{a}$ & 2 \\
\hline $\mathrm{CD} 3+\mathrm{CD} 4+$ & $29^{\mathrm{b}}$ & 2 & $32^{a, b}$ & 1 & $34^{\mathrm{a}}$ & 1 & $30^{\mathrm{b}}$ & 2 \\
\hline CD3+CD8+ & 18 & 2 & 19 & 1 & 18 & 1 & 21 & 2 \\
\hline CD3+CD4+CD28+ & $23^{\mathrm{b}}$ & 1 & $28^{\mathrm{a}}$ & 1 & $29^{a}$ & 1 & $28^{\mathrm{a}}$ & 2 \\
\hline $\mathrm{CD} 3+\mathrm{CD} 8+\mathrm{CD} 28+$ & $16^{\mathrm{b}}$ & 1 & $19^{a}$ & 1 & $19^{\mathrm{a}}$ & 2 & $21^{a}$ & 2 \\
\hline CD4+CD25+FOXP3+ & 4.4 & 0.6 & $5 \cdot 9$ & 0.9 & $6 \cdot 0$ & 1.0 & $6 \cdot 5$ & 0.9 \\
\hline OX6+ (MHC class II+) & $49^{\mathrm{a}}$ & 2 & $42^{\mathrm{b}}$ & 2 & $42^{b}$ & 1 & $39^{\mathrm{b}}$ & 2 \\
\hline $\mathrm{OX} 12+(\lg +)$ & $61^{\mathrm{a}}$ & 2 & $46^{\mathrm{b}}$ & 1 & $44^{b}$ & 1 & $43^{b}$ & 1 \\
\hline CD45RA + & 44 & 2 & 40 & 2 & 41 & 1 & 41 & 2 \\
\hline $\lg M+$ & 48 & 3 & 46 & 1 & 47 & 1 & 44 & 2 \\
\hline $\lg G+$ & $11^{\mathrm{a}}$ & 1 & $8^{\mathrm{b}}$ & 1 & $7^{b}$ & 1 & $8^{\mathrm{b}}$ & 1 \\
\hline CD68+ (macrophages) & 8 & 1 & 8 & 1 & 7 & 1 & 9 & 1 \\
\hline CD11b/c+ (macrophages) & 11 & 2 & 9 & 1 & 9 & 1 & 10 & 2 \\
\hline OX62+OX6+(dendritic cells) & $2 \cdot 1^{\mathrm{a}}$ & 0.6 & $1.0^{\mathrm{b}}$ & 0.1 & $1 \cdot 1^{b}$ & 0.1 & $1 \cdot 2^{\mathrm{b}}$ & 0.1 \\
\hline \multicolumn{9}{|l|}{ Proportionate analysis } \\
\hline$\%$ CD8+ cells that also express CD25+ & $22^{\mathrm{a}}$ & 3 & $12^{\mathrm{b}}$ & 1 & $13^{b}$ & 1 & $10^{\mathrm{b}}$ & 1 \\
\hline$\%$ CD8+ cells that also express CD152+ & $26^{\mathrm{a}}$ & 1 & $17^{\mathrm{b}}$ & 2 & $16^{\mathrm{b}}$ & 2 & $15^{\mathrm{b}}$ & 1 \\
\hline$\%$ CD8+ cells that also express CD71+ & $32^{\mathrm{a}}$ & 2 & $25^{\mathrm{b}}$ & 2 & $25^{\mathrm{b}}$ & 3 & $24^{\mathrm{b}}$ & 2 \\
\hline$\%$ CD4+ cells that also express CD152+ & $9 \cdot 0^{\mathrm{a}}$ & 0.5 & $5 \cdot 6^{\mathrm{b}}$ & 0.6 & $5 \cdot 4^{\mathrm{b}}$ & 0.6 & $5 \cdot 0^{b}$ & 0.9 \\
\hline$\%$ CD4+ cells that also expressCD71+ & 11 & 1 & 10 & 1 & 10 & 1 & 11 & 1 \\
\hline$\%$ OX12+ cells that also express CD27+ & $12^{\mathrm{b}}$ & 1 & $22^{\mathrm{a}}$ & 1 & $22^{\mathrm{a}}$ & 1 & $20^{\mathrm{a}}$ & 2 \\
\hline
\end{tabular}

$\mathrm{CD}$, cluster of differentiation; FOXP3, forkhead box P3.

a,b Mean values within a row with unlike superscript letters were significantly different $(P<0.05)$.

* The following phenotypes were not significantly different among groups ( $n$ 30-39); \%CD3+CD27+: 87 (SEM 1)\%; CD284+: 24 (SEM 1 ) \%; \%CD68+CD284+: 79 (SEM 2) \%; \%CD11+CD284+: 42 (SEM 2) \%; CD3-CD161+: 7.5 (SEM 0.4) \%. Discrepancies between total number of mothers per group and the number here depicted are due to technical difficulties.

Choline metabolism, particularly that of PC in the liver, has been reported to be altered by feeding high-fat diets ${ }^{(24)}$.

We show for the first time that feeding a diet devoid of choline significantly impairs maternal immune function.
T-cell function may be reduced in $\mathrm{D}$ dams due to a lower proportion of $\mathrm{T}$ cells expressing the co-stimulatory molecule CD28, which is crucial for T-cell activation, their proliferation, cytokine secretion and exertion of effector functions ${ }^{(25)}$.

Table 5. Ex vivo mitogen-stimulated splenocyte cytokine production from rat dams fed choline-deficient (D) or choline-sufficient diets $(\mathrm{C} 1, \mathrm{C} 2.5 \text { or } \mathrm{C} 6)^{*}$

(Mean values with their standard errors)

\begin{tabular}{|c|c|c|c|c|c|c|c|c|}
\hline \multirow[b]{2}{*}{ Mitogen } & \multicolumn{2}{|c|}{$\mathrm{D}(n 6)$} & \multicolumn{2}{|c|}{ C1 (n 11) } & \multicolumn{2}{|c|}{$\mathrm{C} 2 \cdot 5(n 10)$} & \multicolumn{2}{|c|}{ C6 (n 11) } \\
\hline & Mean & SEM & Mean & SEM & Mean & SEM & Mean & SEM \\
\hline \multicolumn{8}{|l|}{ LPS (pg/ml) } & 14 \\
\hline $\mathrm{IL}-1 \beta$ & 39 & 6 & 43 & 14 & 62 & 19 & 65 & 18 \\
\hline IL-6 & $424^{\mathrm{b}}$ & 56 & $562^{b}$ & 67 & $825^{a}$ & 93 & $1009^{a}$ & 114 \\
\hline $\mathrm{IL}-10$ & $341^{\mathrm{b}}$ & 79 & $523^{a}$ & 80 & $556^{\mathrm{a}}$ & 58 & $501^{a}$ & 60 \\
\hline TNF- $\alpha$ & 172 & 23 & 156 & 29 & 163 & 37 & 229 & 34 \\
\hline IFN- $\gamma$ & $45^{\mathrm{b}}$ & 15 & $293^{a}$ & 58 & $141^{\mathrm{a}}$ & 36 & $189^{\mathrm{a}}$ & 47 \\
\hline \multicolumn{9}{|l|}{ ConA (pg/ml) } \\
\hline IL-2 & $1455^{\mathrm{b}}$ & 365 & $2964^{a}$ & 233 & $2642^{a}$ & 193 & $2642^{a}$ & 183 \\
\hline IL-6 & $218^{b}$ & 45 & $502^{a}$ & 93 & $489^{a}$ & 96 & $626^{\mathrm{a}}$ & 144 \\
\hline IL-10 & 244 & 62 & 279 & 26 & 331 & 37 & 296 & 39 \\
\hline TNF- $\alpha$ & $35^{\mathrm{b}}$ & 9 & $117^{\mathrm{a}}$ & 19 & $118^{\mathrm{a}}$ & 24 & $155^{\mathrm{a}}$ & 32 \\
\hline IFN- $\gamma$ & $170^{\mathrm{b}}$ & 62 & $853^{a}$ & 180 & $673^{a}$ & 134 & $939^{a}$ & 175 \\
\hline \multicolumn{9}{|l|}{ CD3/CD28 (pg/ml) } \\
\hline IL-2 & $54^{c}$ & 25 & $224^{\mathrm{b}}$ & 51 & $273^{b}$ & 90 & $498^{a}$ & 71 \\
\hline IL-6 & $234^{\mathrm{C}}$ & 84 & $481^{b}$ & 41 & $462^{b}$ & 104 & $867^{a}$ & 217 \\
\hline $\mathrm{IL}-10$ & $80^{b}$ & 27 & $253^{a}$ & 39 & $507^{a}$ & 158 & $345^{\mathrm{a}}$ & 84 \\
\hline TNF- $\alpha$ & $84^{b}$ & 19 & $101^{\mathrm{b}}$ & 19 & $97^{b}$ & 12 & $168^{a}$ & 10 \\
\hline IFN- $\gamma$ & $15^{\mathrm{b}}$ & 2 & $578^{a}$ & 205 & $519^{a}$ & 160 & $650^{\mathrm{a}}$ & 112 \\
\hline
\end{tabular}

LPS, lipopolysaccharide; IFN- $\gamma$, interferon $\gamma$.

a,b Mean values within a row with unlike superscript letters were significantly different $(P<0.05)$

* The amount IL-2 in the media after LPS stimulation was below the detection levels. IL-1 $\beta$ was only measured in the supernatant of LPSstimulated cells. Discrepancies between total number of mothers per group and the number here depicted are due to technical difficulties. 
A reduction of CD28 expression has also been found in other conditions of depressed T-cell function, e.g. in childhood malnutrition $^{(26)}$ and in Fe depletion ${ }^{(27)}$, making this a feasible mechanism to reduce immune response in D splenocytes. At the same time, a higher proportion of D CD8+ T cells carried markers of early and later activation (CD71 and CD25), and their activation in vivo may have contributed to the lower production of IL-2, a marker of proliferation. Proportions of both CD8+CD25+ T cells, known to suppress IL-2 response ${ }^{(28)}$, and of $\mathrm{CD} 152+\mathrm{T}$ cells, involved in the resolution of immune activation ${ }^{(25)}$, are increased in D splenocytes, suggesting an immunosuppression in these dams. The production of IL-2, representing the ability of splenocytes to proliferate, after stimulation with a polyclonal T-cell stimulus (ConA) and a T-cell antigen (CD3/CD28) was 51 and $75 \%$ lower, respectively. This is consistent with a study of feeding adult rats a diet devoid of choline for $60 \mathrm{~d}$, resulting in a much reduced ex vivo proliferative response to ConA compared with animals fed $2.6 \mathrm{~g} / \mathrm{kg}$ choline ${ }^{(12)}$. These animals also showed a reduced hypersensitivity response, providing evidence that T-cell-mediated functions are impaired in vitro ${ }^{(12)}$. We further show that splenocytes of $\mathrm{D}$ animals had a reduced capacity to produce almost all cytokines involved in T-cell function (with the exception of IL-10 after ConA stimulation), which may be due, in part, to the reduced proportion of CD28+ T cells. Importantly, production of IFN- $\gamma$ was considerably reduced in D splenocytes after stimulation. This cytokine is crucial in the response to viral, as well as to some bacterial and protozoal infections ${ }^{(29)}$, and is produced by both CD4+ and CD8+ T cells and by Natural Killer cells $(\mathrm{CD} 3-\mathrm{CD} 161+)^{(30)}$.

LPS activates antigen-presenting cells, including macrophages, dendritic cells and $\mathrm{B}$ cells, by first binding to their Toll-like receptor 4 (CD284). We found no difference in the proportion of splenocytes overall carrying CD284 nor of macrophages with this receptor between any of the dietary groups. Although there was a higher proportion of $\mathrm{B}$ cells $(\mathrm{OX} 12+$ and $\mathrm{IgG}+)$ in the spleen of $\mathrm{D}$ animals, there was a lower proportion of activated OX12+CD27+ B cells, which are the cells that respond to LPS $^{(31)}$. Not ruling out changes in the functional capacity of antigen-presenting cells, the present results are overall suggestive of a depressed T-cell function influencing the cytokine response to LPS. The cytokine most affected in the D splenocyte response to LPS was IFN- $\gamma$, which is also involved in the activation of macrophages and induces the MHC Class II, again affecting the response to LPS $^{(32)}$. A reduced activation of antigen-presenting cells as represented by fewer OX12+CD27+ B cells and reduced IFN- $\gamma$ production probably exacerbates the reduced $\mathrm{T}$-cell function in response to LPS. Cells do not proliferate to any great extent when stimulated with LPS, and this probably explains the failure of an earlier study to demonstrate a significantly lower proliferative response to LPS in splenocytes from choline-deficient adult rats ${ }^{(12)}$. It is possible that the effect on body weight contributed to the reduced immune function in the dams fed the devoid diet; however, this immunosuppression was not observed in the C6 choline group where body weight was similar. This suggests that the immune effects are more likely due to a limited supply of choline than a reduced food intake or lower body weight.

The optimal choline content in the diet of lactating dams is not known and may be higher when a high-fat diet is fed, such as during breeding. Most commercial diets contain $1 \cdot 0-$ $2.5 \mathrm{~g}$ choline $/ \mathrm{kg}$ diet that is usually provided, as was in the present study, as a choline salt. The present study confirms that supplementing a high-fat diet with $1 \mathrm{~g}$ choline/kg (in the form of salt) is equal to supplementing with $2.5 \mathrm{~g}$ choline $/ \mathrm{kg}$ with respect to maintaining maternal and infant weight. Similarly, based on the immune measures collected in the present study, we found very little difference in the immune response between the $\mathrm{C} 1$ and $\mathrm{C} 2 \cdot 5$ dams. The only difference between the two diets was a substantially higher (150\%) production of IL- 6 by C 2.5 splenocytes after stimulation with LPS, suggestive of a more robust macrophage response. Although CD4+ T cells might produce some IL-6, an effect on T-cell function can be ruled out as there was no difference in response to either of the T-cell mitogens between $\mathrm{C} 1$ and $\mathrm{C} 2.5$. A source of choline has been demonstrated to be required for the release of IL- 6 by macrophages stimulated with LPS ${ }^{(33)}$. Recently, it was also demonstrated that LPS stimulates the release of acetylcholine from macrophages, which is involved in the induction of their inflammatory response ${ }^{(34)}$. This suggests that the $2.5 \mathrm{~g}$ choline $/ \mathrm{kg}$ diet may have some benefit over the $1 \mathrm{~g} / \mathrm{kg}$ diet to support the dam's innate immune system.

Our data suggest for the first time that there may be an upper level of intake during lactation for the health of both dam and offspring. Feeding the highest level of choline $(6.2 \mathrm{~g} / \mathrm{kg}$ diet, approximately six times the concentration in most research diets) had negative effects on maternal and pup body weight. Whether the lower pup body weight was due to the higher total choline content, the higher amount of free choline or the different balance of choline containing metabolites (lower proportion of GPC, PC and lysophosphocholine in stomach contents) cannot be determined by the present study. A recent study has been designed specifically to address that choline toxicity did not observe any negative effects in adult mice given a relatively low daily oral gavage of $200 \mathrm{mg}$ choline chloride/ $\mathrm{kg}$ body weight (approximately $150 \mathrm{mg}$ choline/kg body weight) for $28 \mathrm{~d}^{(35)}$. The present study found no effects on growth, food and water intake, total leucocyte concentration, neutrophils, lymphocytes, eosinophils, monocytes and number of spleen mononuclear cells ${ }^{(35)}$. We estimated that the dams in the present study consumed a much higher amount of choline (approximately $248 \mathrm{mg}$ choline/d or $1240 \mathrm{mg}$ choline/kg body weight based on $200 \mathrm{~g}$ body weight and $40 \mathrm{~g} / \mathrm{d}$ food intake), which may furthermore differ during periods of high choline demand, such as early life, pregnancy and lactation. There is a growing literature on the possible toxicity of trimethylamine- $\mathrm{N}$-oxide to humans, a metabolic product of $\mathrm{PC}^{(36)}$, but this has, to our knowledge, not been associated with the intake of choline in the form of a salt.

Despite the effect on body weight and breast milk composition (stomach content of the pups), there were minimal effects of feeding the C6 diet on maternal immune function. 
The weight and, with that, total amount of cells in the spleen was lower in C6 than in C1; however, there was no substantial difference in the proportion of different cells present compared with the other groups fed choline, nor did the cytokine response to LPS and ConA differ among the cholinecontaining diet groups. Nevertheless, $T$ cells were more robustly activated when stimulated through the $\mathrm{T}$-cell receptor (CD3/CD28), so that there was a higher production of proinflammatory IL-2, IL-6 and TNF- $\alpha$ in cells from C6 dams. There are numerous studies in adult rodents demonstrating an increase in choline and its metabolites in brain after feeding diets high in choline (reviewed in Babb et al. ${ }^{(37)}$ ). It is likely that choline concentration is also increased in lymphocytes in those animals, which may result in higher production of choline-derived metabolites as T cells, including their cholinergic system and, when stimulated via the T-cell receptor complex, cells may produce more acetylcholine that induces their activation $^{(38)}$. To analyse this mechanism and its physiological consequences would require further studies.

The results of the present study confirm that choline is required in the maternal diet during lactation, not only for maternal and pup growth but also to maintain maternal immune function, both $\mathrm{T}$ cell and innate immunity. The current recommendation of $1 \mathrm{~g}$ choline $/ \mathrm{kg}$ diet in a high-fat diet appears sufficient to maintain T-cell function; however, there may be some benefits to innate immunity of feeding $2.5 \mathrm{~g}$ choline $/ \mathrm{kg}$. Exceeding this minimal recommendation by 6-fold (in the form of a choline salt) was associated with a higher concentration of choline in breast milk and negative effects on maternal and pup body weight and resulted in increased activation of T-cell function when stimulated via the T-cell receptor. The translation of this higher intake to humans is not possible as the current Institute of Medicine recommendation is that of an adequate intake, but suggests that there may be concern if women were to use very high amounts of supplement choline salts during lactation.

\section{Acknowledgements}

The authors would like to acknowledge the technical assistance of Nicole Coursen, Kelly-Ann Leonard, Yeping Xiong, Peter Iglinski and Howe-Ming Yu and Yuan Yuan Zhao.

The present study was funded by the Natural Science and Engineering Council of Canada (grant numbers NSERC RGPIN 121610 and 386652) and Quality Food for Health grant from the ALMA, Alberta Innovates Biosolutions and the Egg Farmers of Alberta (grant number 2012Q005R). This work was further supported by the Women and Children's Health Research Institute (E. D. L., Graduate Studentship and the Queen Elizabeth II Graduate Scholarship), from the Canadian Institutes of Health Research Postdorctoral Fellowship, Fonds de Recherche en Santé du Québec and Izaak Walton Killam Memorial Postdoctoral Fellowships (all C. R.). None of the funders had any role in the design and analysis of the study or in the writing of this article.

None of the authors has any conflict of interest to declare.

The authors' contributions are as follows: N. S. D. conducted the study, analysed and interpreted the results, and wrote the manuscript with C. J. F.; C. J. F., R. L. J. and J. M. C. formulated the research questions, designed the study and secured the funding for the study; S. G., E. D. L., M. R. R. and C. R. helped in method development, conducting the study or the analysis of the results. All authors reviewed and edited the manuscript.

\section{References}

1. Collier B \& Lang C (1969) The metabolism of choline by a sympathetic ganglion. Can J Physiol Pharmacol 47, 119-126.

2. Voelker DR \& Kennedy EP (1982) Cellular and enzymic synthesis of sphingomyelin. Biochemistry (Mosc) 21 , 2753-2759.

3. Hove EL \& Copeland DH (1954) Progressive muscular dystrophy in rabbits as a result of chronic choline deficiency six figures. J Nutr 53, 391-405.

4. Zeisel SH, Da Costa KA, Franklin PD, et al. (1991) Choline, an essential nutrient for humans. FASEB J 5, 2093-2098.

5. Shaw GM, Carmichael SL, Yang W, et al. (2004) Periconceptional dietary intake of choline and betaine and neural tube defects in offspring. Am J Epidemiol 160, 102-109.

6. Zeisel SH, Mar MH, Zhou Z, et al. (1995) Pregnancy and lactation are associated with diminished concentrations of choline and its metabolites in rat liver. J Nutr $\mathbf{1 2 5}$, 3049-3054.

7. Lewis ED, Subhan FB, Bell RC, et al. (2014) Estimation of choline intake from $24 \mathrm{~h}$ dietary intake recalls and contribution of egg and milk consumption to intake among pregnant and lactating women in Alberta. Br J Nutr 112, 112-121.

8. Gebhardt BM \& Newberne PM (1974) Nutrition and immunological responsiveness: T-cell function in the offspring of lipotrope- and protein-deficient rats. Immunology 26, 489 .

9. Rosas-Ballina M \& Tracey KJ (2009) Cholinergic control of inflammation. J Intern Med 265, 663-679.

10. Hosea Blewett HJ, Cicalo MC, Holland CD, et al. (2008) The immunological components of human milk. Adv Food Nutr Res 54, 45-80.

11. Palmer AC (2011) Nutritionally mediated programming of the developing immune system. Adv Nutr 2, 377-395.

12. Courrèges MC, Benencia F, Uceda A, et al. (2003) Effect of dietary choline deficiency on immunocompetence in Wistar rats. Nutr Res 23, 519-526.

13. Reeves PG, Nielsen FH \& Fahey GC Jr (1993) AIN-93 purified diets for laboratory rodents: final report of the American Institute of Nutrition ad boc writing committee on the reformulation of the AIN-76A rodent diet. $J$ Nutr 123, 1939-1951.

14. Xiong Y, Zhao Y-Y, Goruk S, et al. (2012) Validation of an LC-MS/MS method for the quantification of choline-related compounds and phospholipids in foods and tissues. J Chromatogr B 911, 170-179.

15. Folch J, Lees M \& Sloane-Stanley GH (1957) A simple method for the isolation and purification of total lipides from animal tissues. J Biol Chem 226, 497-509.

16. Bligh EG \& Dyer WJ (1959) A rapid method of total lipid extraction and purification. Can J Biochem Physiol 37, 911-917.

17. Field CJ, Wu G, Metroz-Dayer MD, et al. (1990) Lactate production is the major metabolic fate of glucose in splenocytes and is altered in spontaneously diabetic BB rats. Biochem $J$ 272, $445-452$. 
18. Field CJ, Thomson CA, Van Aerde JE, et al. (2000) Lower proportion of CD45R0+ cells and deficient interleukin-10 production by formula-fed infants, compared with humanfed, is corrected with supplementation of long-chain polyunsaturated fatty acids. J Pediatr Gastroenterol Nutr 31, 291-299.

19. Blewett HJ, Gerdung CA, Ruth MR, et al. (2009) Vaccenic acid favourably alters immune function in obese JCR:LA-cp rats. Br J Nutr 102, 526.

20. Rohlfs E, Garner S, Mar M-H, et al. (1993) Glycerophosphocholine and phosphocholine are the major choline metabolites in rat milk. J Nutr 123, 1762-1768

21. Ilcol Y, Ozbek R, Hamurtekin E, et al. (2005) Choline status in newborns, infants, children, breast-feeding women, breast-fed infants and human breast milk. $J$ Nutr Biochem 16, 489-499.

22. Samborski RW, Ridgway ND \& Vance DE (1993) Metabolism of molecular species of phosphatidylethanolamine and phosphatidylcholine in rat hepatocytes during prolonged inhibition of phosphatidylethanolamine $N$-methyltransferase. J Lipid Res 34, 125-137.

23. Holmes-McNary MQ, Cheng WL, Mar MH, et al. (1996) Choline and choline esters in human and rat milk and in infant formulas. Am J Clin Nutr 64, 572-576.

24. Noga AA \& Vance DE (2003) Insights into the requirement of phosphatidylcholine synthesis for liver function in mice. J Lipid Res 44, 1998-2005.

25. Rudd CE, Taylor A \& Schneider H (2009) CD28 and CTLA-4 coreceptor expression and signal transduction. Immunol Rev 229, $12-26$.

26. Nájera O, González C, Cortés E, et al. (2007) Effector $\mathrm{T}$ lymphocytes in well-nourished and malnourished infected children. Clin Exp Immunol 148, 501-506.

27. Kuvibidila SR \& Porretta C (2003) Iron deficiency and in vitro iron chelation reduce the expression of cluster of differentiation molecule (CD)28 but not $\mathrm{CD} 3$ receptors on murine thymocytes and spleen cells. Br J Nutr 90, 179-189.
28. McNally A, Hill GR, Sparwasser T, et al. (2011) CD4+CD25+ regulatory $\mathrm{T}$ cells control $\mathrm{CD} 8+\mathrm{T}$-cell effector differentiation by modulating IL-2 homeostasis. Proc Natl Acad Sci US A 108, 7529-7534.

29. Magombedze G, Reddy PBJ, Eda S, et al. (2013) Cellular and population plasticity of helper CD4+ T cell responses. Front Physiol 4, 206.

30. Boehm U, Klamp T, Groot M, et al. (1997) Cellular responses to interferon- $\gamma$. Annu Rev Immunol 15, 749-795.

31. Rickert RC, Jellusova J \& Miletic AV (2011) Signaling by the tumor necrosis factor receptor superfamily in B-cell biology and disease. Immunol Rev 244, 115-133.

32. Schroder K, Sweet MJ \& Hume DA (2006) Signal integration between IFN $\gamma$ and TLR signalling pathways in macrophages. Immunobiology 211, 511-524.

33. Tian Y, Pate C, Andreolotti A, et al. (2008) Cytokine secretion requires phosphatidylcholine synthesis. I Cell Biol 181, 945-957.

34. Lv Y, Hu S, Lu J, et al. (2014) Upregulating nonneuronal cholinergic activity decreases TNF release from lipopolysaccharide-stimulated RAW264.7 cells. Mediators Inflamm 2014, 873728 .

35. Mehta AK, Arora N, Gaur SN, et al. (2009) Acute toxicity assessment of choline by inhalation, intraperitoneal and oral routes in Balb/c mice. Regul Toxicol Pharmacol 54, 282-286.

36. Miller CA, Corbin KD, da Costa K-A, et al. (2014) Effect of egg ingestion on trimethylamine- $N$-oxide production in humans: a randomized, controlled, dose-response study. Am J Clin Nutr 100, 778-786.

37. Babb SM, Ke Y, Lange N, et al. (2004) Oral choline increases choline metabolites in human brain. Psychiatry Res Neuroimaging 130, 1-9.

38. Fujii T, Takada-Takatori Y \& Kawashima K (2007) Roles played by lymphocyte function-associated antigen-1 in the regulation of lymphocytic cholinergic activity. Life Sci $\mathbf{8 0}$, $2320-2324$. 